\title{
RADIOCARBON AND TRITIUM LEVELS ALONG THE ROMANIAN LOWER DANUBE RIVER
}

\author{
Carmen Varlam ${ }^{1,2}$ • Ioan Stefanescu ${ }^{1}$ • Stela Cuna $^{3}$ • Irina Vagner ${ }^{1}$ - Ionut Faurescu ${ }^{1}$ • \\ Denisa Faurescu ${ }^{1}$
}

\begin{abstract}
The Lower Danube Basin covers the Romanian-Bulgarian sub-basin downstream from Cazane Gorge and the sub-basins of the Siret and Prut rivers. To extensively survey the Romanian nuclear power plant impact on the Danube water, tritium and radiocarbon baseline values are required. Therefore, the reported study tried to establish these values based on a 2-yr sampling campaign covering $975 \mathrm{~km}$ of the Danube from Cazane Gorge to Tulcea. The tributaries Cerna, Jiu, Olt, and Arges were also included in this study. During the sampling campaigns, tritium concentration of different sampling locations showed values between $7 \pm 2.1$ and $33.5 \pm 2.3 \mathrm{TU}$. Measured ${ }^{14} \mathrm{C}$ activity for the same locations ranged between $88.45 \pm 1.46$ and $112.36 \pm 1.56$ pMC. Lower values were recorded for tributaries: between $8.3 \pm 2.1$ and $12.2 \pm 2.2 \mathrm{TU}$ for tritium and between $67.3 \pm 1.29$ and $86.04 \pm 1.42 \mathrm{pMC}$ for ${ }^{14} \mathrm{C}$. Despite the nuclear activity in the observed areas, tritium and ${ }^{14} \mathrm{C}$ activities presented slightly higher values for specific locations without any influence on Danube River water.
\end{abstract}

\section{INTRODUCTION}

Rivers are important freshwater sources, and much of the world's population has relied on rivers for its development. In recent years, many international and national hydrology research programs have focused on large river basins. In humid basins, precipitation processes are the primary signal traced by river discharge. Evidence that precipitation input signals are not static is found from long-term isotope records of European rivers. Interannual variations of these processes reflect the inherent decadal variability of precipitation processes. Comparing tritium levels in the Danube River with tritium levels in precipitation at Vienna (Rank et al. 1998) reveals that not only short-term signals but also long-term changes in the isotope ratio of precipitation are transmitted through the catchments and can be detected in river water. A comparison of measured and modeled ${ }^{3} \mathrm{H}$ contents in the Danube River revealed that the best fit that could be obtained (mean residence time of $3 \mathrm{yr}$ ) is still not satisfactory (Rank et al. 2005).

The Danube River Basin is the second largest river basin in Europe, covering 801,463 km² (ICPDR 2005). It lies west of the Black Sea in central and southeastern Europe. Due to its geological and geographical conditions, the Danube River Basin can be divided into 3 main parts: the Upper, Middle, and Lower Danube Basin. About 65\% of the Lower Danube Basin forms the natural border between Romania and Bulgaria. Two important nuclear power plants (NPP) for both countries are found in this region: Kozloduy NPP and Cernavoda NPP. Both countries consider nuclear energy to be a potential energy solution for future economic development. In fact, nuclear power generates between $10 \%$ and $45 \%$ of the electricity for the Danube riparian countries. Therefore, Romania has already built a new CANDU (CANada Deuterium Uranium)-type unit in Cernavoda, which was put into operation in 2007, and Bulgaria started negotiations for a new NPP in Belene (also situated on the Danube River).

Radiocarbon $\left({ }^{14} \mathrm{C}\right)$ in the nuclear fuel cycle is produced by neutron interaction with ${ }^{13} \mathrm{C},{ }^{14} \mathrm{~N},{ }^{15} \mathrm{~N}$, ${ }^{16} \mathrm{O}$, and ${ }^{17} \mathrm{O}$, which may be present in the nuclear fuels as well as the moderator and primary coolant systems of nuclear reactors. Tritium is produced in nuclear power reactors during the fission of

\footnotetext{
${ }^{1}$ Institute for Cryogenics and Isotopic Technologies, Ramnicu Valcea, Romania.

${ }^{2}$ Corresponding author. Email: cvarlam@icsi.ro.

${ }^{3}$ Institute for Isotopic and Molecular Technologies, Cluj Napoca, Romania.
}

(C) 2010 by the Arizona Board of Regents on behalf of the University of Arizona Proceedings of the 20th International Radiocarbon Conference, edited by A J T Jull RADIOCARBON, Vol 52, Nr 2-3, 2010, p 783-793 
heavy nuclei and by neutron interaction with coolants, moderators, and some light elements, such as lithium, beryllium, and boron. ${ }^{14} \mathrm{C}$ and tritium production rates depend on the type of reactor and its capacity. By determining the levels of tritium and ${ }^{14} \mathrm{C}$ in the Lower Danube Basin, 2 important types of information are provided: first, as input values to asses the environmental radioactivity levels (Cernavoda is a CANDU type reactor, where tritium and ${ }^{14} \mathrm{C}$ are evacuated in gaseous and liquid effluents [IAEA 2004]), and second, as data for the primary estimation of the river discharge signature. This is important for the transborder underground water reservoir situated between Romania and Bulgaria (Figure 1).

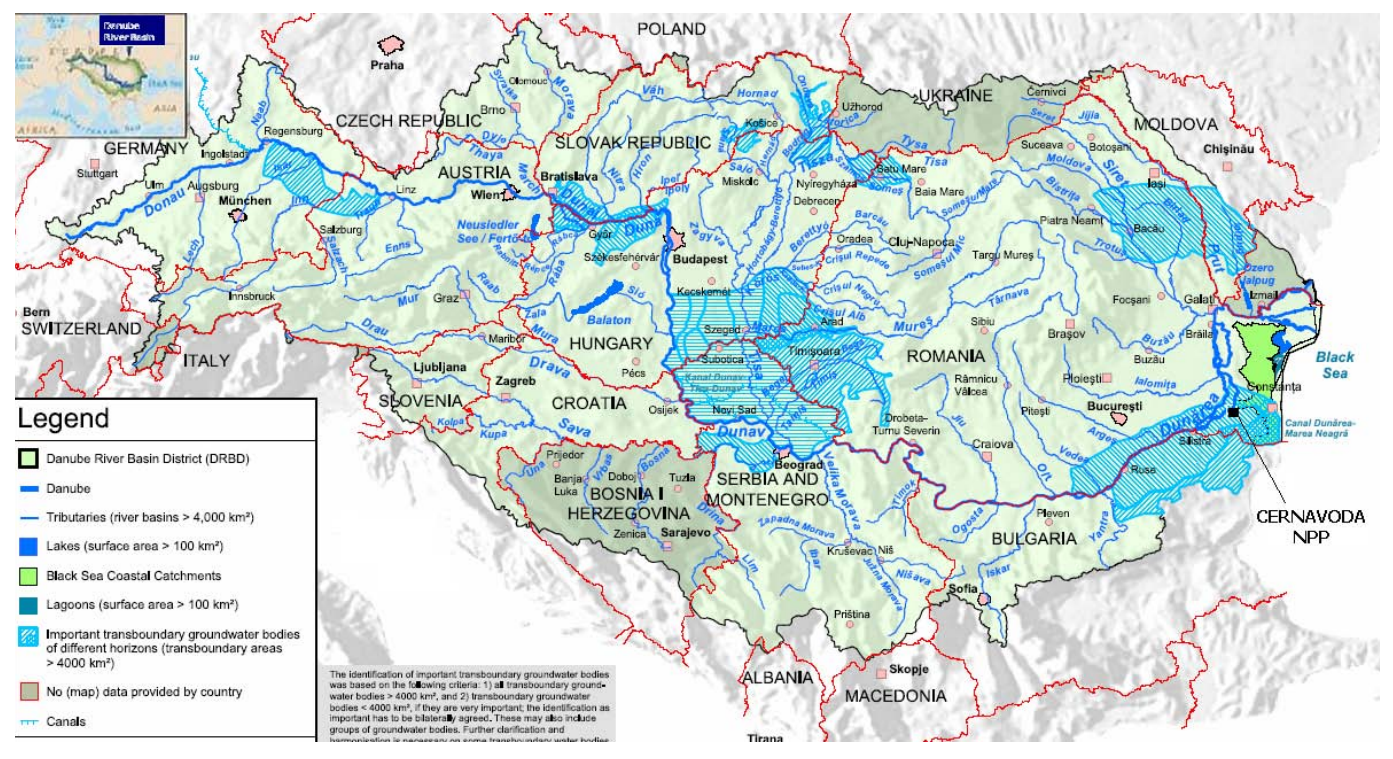

Figure 1 Underground water reservoirs from the Danube River Basin (modified from The Danube River Basin District—Part A [ICPDR 2005]).

We must emphasize that the data for the Lower Danube Basin regarding tritium and ${ }^{14} \mathrm{C}$ levels in river water are missing, and no sampling or measurement campaigns were conducted in the last $5 \mathrm{yr}$ (at least there is no reporting of it). However, it is well known that the technical services staff of NPPs were in charge of environment radioactivity monitoring, but their work is limited only to a specific area around the NPPs, and their data cannot be used to estimate the tritium and ${ }^{14} \mathrm{C}$ baselines of this part of the Danube.

\section{SAMPLING LOCATIONS}

Danube typology represents a harmonized system developed by the countries sharing the Danube River Basin (ICPDR 2005). The most important factors used for this system are the mean water slope, substratum composition, geomorphology, and water temperature. The Lower Danube Basin contains 4 sections: Iron Gates Danube, Western Pontic Danube, Eastern Wallachian Danube, and Danube Delta. The discharge regime of the Danube River is influenced by regional precipitation, especially precipitation from the Alps and Carpathian Mountains. The mean flow rate varies along the Danube from $1900 \mathrm{~m}^{3} / \mathrm{s}$ in the Upper Danube to $6500 \mathrm{~m}^{3} / \mathrm{s}$ where the Danube reaches the Black Sea. 
The Iron Gates Danube section (A, Figure 2) has an average width of about $750 \mathrm{~m}$ and runs through a canyon and a valley. This section is characterized by a high current velocity (from 1.8 to $5 \mathrm{~m} / \mathrm{s}$ ). The chosen sampling point was Ieselnita (1, Figure 2), a location with easy access to the south side of the Danube. The next sampling point was Cerna, a Danube tributary, at Toplet (2, Figure 2). Cerna is a small mountain river without industrial activity. At the end of this section is Turnu Severin (3, Figure 2), another sampling point.

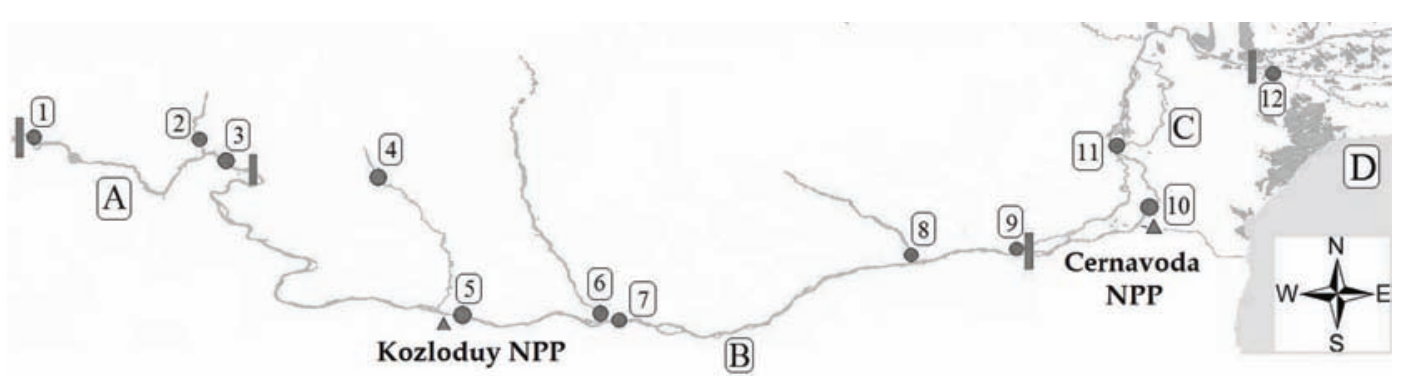

Figure 2 Section type and sampling areas from the Lower Danube Basin: A-Iron Gates Danube; B-Western Pontic Danube; C-Eastern Wallachian Danube; D-Danube Delta.

The Western Pontic Danube section (B, Figure 2) contains a floodplain landscape with higher plains of terraced accumulation in a meander and plain floodplain valley. The main channel has an average width of $830 \mathrm{~m}$ and a mean depth of $8.5 \mathrm{~m}$. This section is characterized by moderate values of current velocity of $1.30 \mathrm{~m} / \mathrm{s}$. The diversity of water bodies in this area close to the stream is wide, but we focused on the main course and few tributaries with significant mining industry: the Jiu River (4, Figure 1), and chemical industry, the Olt River (6, Figure 2) and Arges River (8, Figure 2). The Bechet location (5, Figure 2), from the main course, is important because it is situated downstream from the Kozloduy NPP. Another sampling point was Tr.-Magurele (7, Figure 2), located downstream from the Olt River, approximately in the middle of this section. At the end of this section is Chiciu-Silistra (9, Figure 2), another important sampling point, before the Danube splits into 2 branches, the Old Danube and Borcea.

The Danube changes its watercourse northward in the Eastern Wallachian Danube section (C, Figure 2). There are 2 large isles, Balta Ialomitei and Balta Brailei, and many natural lakes. The main channel has an average width of $650 \mathrm{~m}$, and a mean depth of $10.5 \mathrm{~m}$. The section is characterized by slow current velocities of $0.8 \mathrm{~m} / \mathrm{s}$. The first sampling point of this section was established in Seimeni (10, Figure 2), downstream from the Cernavoda NPP discharge channel, and the second in Giurgeni (11, Figure 2), a point between the 2 isles where the Danube has 1 main branch for a short distance.

The Danube Delta section (D, Figure 2) is the most recent Romanian territory. There are 3 main water channels: Chilia, Sulina, and Sf. Gheorghe, with numerous canals and floating islands. This section is characterized by average current velocities of $0.7 \mathrm{~m} / \mathrm{s}$. The shape of the delta is triangular, and at mean water levels $60 \%$ of this area is covered by water. We established a sampling point at Tulcea (12, Figure 2) on the main course before the Danube splits into the Sulina and Sf. Gheorghe branches. Initially, there were more sampling locations in the Danube Delta, but due to difficult access (only by boat) and considering the critical atmospheric conditions during the sampling campaigns, we decided to abandon those locations. The sampling points from the studied areas are shown in Table 1 with their geographical coordinates. 
Table 1 Geographical coordinates of sampling locations.

\begin{tabular}{clllll}
\hline Location & Location name & Section type & Water body & Latitude (N) & Longitude (E) \\
\hline 1 & Ieselnita & A & Danube & $44^{\circ} 48^{\prime} 31^{\prime \prime}$ & $21^{\circ} 24^{\prime} 11^{\prime \prime}$ \\
2 & Toplet & A & Cerna & $44^{\circ} 47^{\prime} 58^{\prime \prime}$ & $22^{\circ} 23^{\prime} 26^{\prime \prime}$ \\
3 & Drobeta Turnu Severin & A & Danube & $44^{\circ} 40^{\prime} 2^{\prime \prime}$ & $22^{\circ} 32^{\prime} 51^{\prime \prime}$ \\
4 & Filiasi & B & Jiu & $44^{\circ} 34^{\prime} 8^{\prime \prime}$ & $23^{\circ} 27^{\prime} 19^{\prime \prime}$ \\
5 & Bechet & B & Danube & $44^{\circ} 44^{\prime} 56^{\prime \prime}$ & $23^{\circ} 57^{\prime} 14^{\prime \prime}$ \\
6 & Islaz & B & Olt & $43^{\circ} 44^{\prime} 38^{\prime \prime}$ & $24^{\circ} 46^{\prime} 46^{\prime \prime}$ \\
7 & Turnu Magurele & B & Danube & $43^{\circ} 42^{\prime} 45^{\prime \prime}$ & $24^{\circ} 53^{\prime} 25^{\prime \prime}$ \\
8 & Oltenita & B & Arges & $44^{\circ} 05^{\prime} 51^{\prime \prime}$ & $26^{\circ} 38^{\prime} 12^{\prime \prime}$ \\
9 & Chiciu/Silistra & B & Danube & $44^{\circ} 07^{\prime} 56^{\prime \prime}$ & $27^{\circ} 16^{\prime} 19^{\prime \prime}$ \\
10 & Seimeni & C & Danube & $44^{\circ} 23^{\prime} 31^{\prime \prime}$ & $28^{\circ} 03^{\prime} 28^{\prime \prime}$ \\
11 & Giurgeni & C & Danube & $44^{\circ} 45^{\prime} 2^{\prime \prime}$ & $27^{\circ} 52^{\prime} 17^{\prime \prime}$ \\
12 & Tulcea & D & Danube & $45^{\circ} 10^{\prime} 58^{\prime \prime}$ & $28^{\circ} 48^{\prime} 25^{\prime \prime}$ \\
\hline
\end{tabular}

\section{SAMPLING AND MEASUREMENT TECHNIQUES}

Precipitation sampling was performed on a monthly basis with a typical rainwater collector (IAEA 1989) in the Drobeta Turnu Severin location, starting in the month of January in the period 20062008. The rainwater collector was comprised of 2 valves before a water-collecting container (one to open and close the container and the other to change the container). The collecting container is only opened during rains to prevent evaporation. At the end of the month, the container was shaken thoroughly and a 1-L sample was filled for shipment to the analytical laboratory.

Particular attention was paid to the collection and preservation of the water sample (APHA-AWWAWEF 1995). Water samples for tritium measurement were collected at $1 \mathrm{~m}$ from the left bank of the Danube, at $10 \mathrm{~cm}$ from the water surface, in brown glass bottles. The $\mathrm{pH}$, conductivity, and temperature of the water sample were measured at the sampling location using a portable apparatus WTV $\mathrm{pH} /$ cond 340i. $\mathrm{HCO}_{3}$ was also estimated on site using a HANNA alkalinity test kit.

As tritium is a soft beta emitter ( $5.72 \mathrm{keV}$ mean energy), liquid scintillation is the most appropriate technique for a large number of samples. We used the low-background liquid scintillation spectrometer Quantulus $1220^{\mathrm{TM}}$ (Wallac) to determine tritium in water samples. The analytical method used to determine tritium in water samples was, briefly, the following: samples were filtered through slow depth filters; $250 \mathrm{~mL}$ of filtrate was distilled using the ISO method (ISO 1989); $8 \mathrm{~mL}$ of distillate was mixed with $12 \mathrm{~mL}$ of scintillation cocktail OptiPhase HiSafe 3 (PerkinElmer) in polyethylene vials. Three background samples and tritium standards were simultaneously prepared for each batch. Samples, backgrounds, and tritium standards were counted using the Quantulus 1220 for 1000 min per sample. Tritium standards were internal standard capsules containing a tritium-labeled organic compound [fructose-1 $-{ }^{3} \mathrm{H}$ ] provided by PerkinElmer. Tritium-free water (blank water) was deuterium-depleted water with a $\mathrm{D} /(\mathrm{D}+\mathrm{H})$ value of $15 \mathrm{ppm}$ (Varlam et al. 2009). Counting efficiency at the best factor of merit was between $24.84 \%$ and $25.02 \%$, and the background between $0.714 \pm 0.016$ and $0.748 \pm 0.017 \mathrm{cpm}$ (counts per minute), following a minimum detectable activity of around $4 \mathrm{TU}$ (confidence level of $2 \sigma$ ). The uncertainty due to the statistical nature of radioactive decay and background radiation was reported at $1 \sigma$.

The $\mathrm{CO}_{2}$ direct-absorption method for preparing samples for ${ }^{14} \mathrm{C}$ analysis by liquid scintillation counting (Leaney et al. 1994) is currently applied in our laboratory. For this method, a minimum of $2.6 \mathrm{~g}$ of $\mathrm{CO}_{2}$ as dissolved inorganic carbon (DIC) in the water sample is estimated to be necessary. Due to the large amount of sample needed for ${ }^{14} \mathrm{C}$ measurement by the direct absorption method, the 
DIC precipitated from water samples was made on site according to environmental protection laws. In this way, the DIC presence in $\sim 80 \mathrm{~L}$ of water was reduced to a volume $<1 \mathrm{~L}$. Barium carbonate from precipitate was then acidified to release carbon dioxide, which was the purified. A similar procedure was applied to generate $\mathrm{CO}_{2}$ from $\mathrm{CaCO}_{3}$ using standard carbonate material (modern marine shell) and background carbonate material (marble). The last step of the preparation procedure was to absorb $\mathrm{CO}_{2}$ in the form of carbamate, and to ensure that exactly the same amount was absorbed for each sample, standard, and background. The vials were then counted via conventional ${ }^{14} \mathrm{C}$ analysis using the following parameters: $1500 \mathrm{~min}$ counting time $(15 \times 100 \mathrm{~min} / \mathrm{cycle})$, counting efficiency at the best factor of merit was between $64.88 \%$ and $65.13 \%$ with a marble background between $2.276 \pm 0.044$ and $2.330 \pm 0.045 \mathrm{cpm}$. The uncertainty due to the statistical nature of radioactive decay and background radiation was reported at $1 \sigma$. Applying the validation procedure (Varlam et al. 2005), we established a mean activity for marine shell of $0.2178 \pm 0.0039 \mathrm{~Bq} / \mathrm{g} \mathrm{C}$ (114.18 $\pm 1.82 \mathrm{pMC}$ ), referred to the decay-corrected 95\% NBS oxalic acid activity and adjusted to $\delta^{13} \mathrm{C}=-25 \%$. Each ${ }^{14} \mathrm{C}$ activity was corrected by its individual $\delta^{13} \mathrm{C}$ value. The ${ }^{13} \mathrm{C} /{ }^{12} \mathrm{C}$ ratio was measured by isotope ratio mass spectrometry on a Delta V IRMS on small aliquots of $\mathrm{CO}_{2}$ gas. Values are given relative to the VPDB standard, with overall precision typically $\pm 0.1 \%$.

\section{EXPERIMENTAL RESULTS}

Four sampling campaigns were carried out in August 2006, March and October 2007, and April 2008. Considering the surface water as an indicator of the isotopic composition of precipitation, it was decided that the precipitation from Drobeta Turnu Severin (located at the beginning of the monitored area) should be monitored monthly during the entire period 2006-2008. The average fallout during the year 2006 in Romania was $36.5 \mathrm{~mm}$, lower than the normal climatologic average, while for 2007 and 2008, it was 84.9 and $27 \mathrm{~mm}$, respectively, higher than the normal climatologic average (Romanian National Meteorology Administration, http://www.inmh.ro/index.php/id=402).

Tritium concentration during the year 2006 at the Turnu Severin location averaged $10.7 \pm 2.1 \mathrm{TU}$ (1 tritium unit, TU, corresponds to 1 tritium atom per $10^{18}$ hydrogen atom). A minimum tritium concentration of $5.1 \pm 2.1 \mathrm{TU}$ in January 2006 (Figure 3) and a maximum tritium concentration of $19.6 \pm 2.2 \mathrm{TU}$ in June 2006 have been recorded. Tritium concentration during 2007 for the same location had an average of $10.6 \pm 2.1 \mathrm{TU}$ with a minimum tritium concentration of $6.1 \pm 2.1 \mathrm{TU}$ in February 2007 and a maximum tritium concentration of $17.2 \pm 2.2$ TU in May 2007. Tritium concentration during 2008 at the Drobeta Turnu-Severin location averaged $11.1 \pm 2.1 \mathrm{TU}$. The minimum tritium concentration of $6.7 \pm 2.1 \mathrm{TU}$ was recorded for samples collected in January 2008 and the maximum tritium concentration of $18.8 \pm 2.1 \mathrm{TU}$ occurred in May 2008. This consistent annual fluctuation in tritium concentration happens during the late spring and early summer, when tritium produced in the upper layer of the atmosphere is brought down to the Earth by precipitation. The published values for tritium average in precipitation in Austria (Kralik et al. 2005) ranged between 15.2 TU in 1997 and 10.46 TU in 2002, with a constant value around $10 \mathrm{TU}$ for 2000, 2001, and 2002. The same trend (with respect to the measurement uncertainties) was recorded for Drobeta Turnu Severin precipitation: $10.7 \pm 2.1 \mathrm{TU}$ for 2006, $10.6 \pm 2.1 \mathrm{TU}$ for 2007, and $11.1 \pm 2.1 \mathrm{TU}$ for 2008. There are no other influences from industrial activity for this location, and tritium behavior in precipitation has the typical tendency to decrease in the environment (Clark and Fritz 1997).

An average value of $15.8 \pm 2.2 \mathrm{TU}$ for tritium concentration in samples from Danube water along the Lower Danube Basin has been recorded during the $2 \mathrm{yr}$ of sampling campaigns (Figure 4). This value is close to the average tritium concentration value of $10.8 \pm 2.1 \mathrm{TU}$ in precipitation (with respect to the measurement uncertainties). The reference location for the Romanian Danube water 


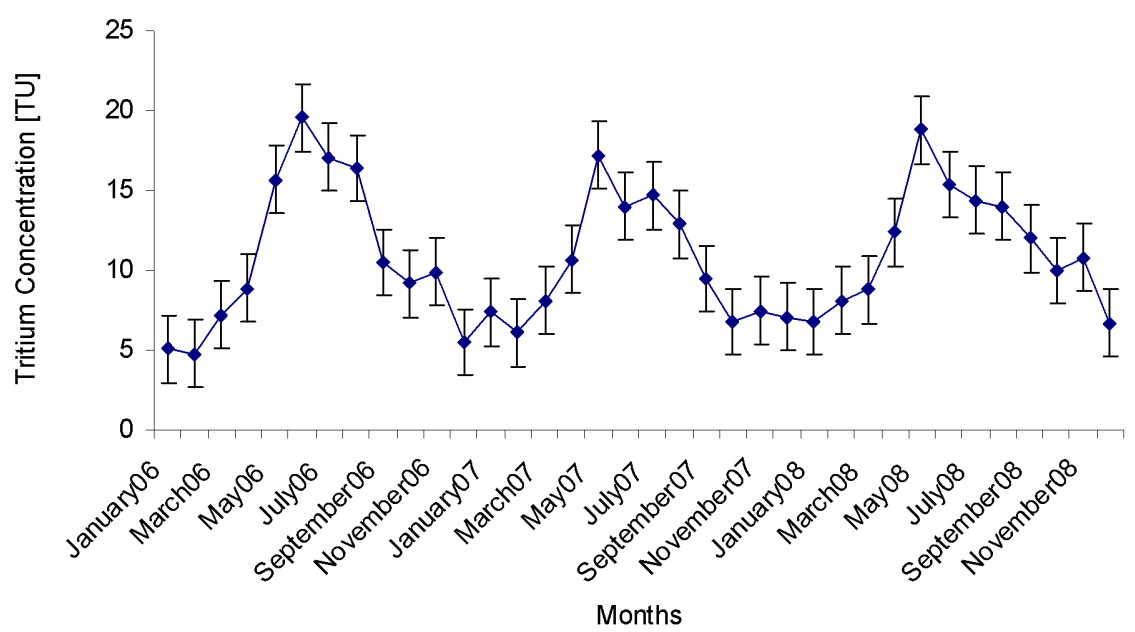

Figure 3 Tritium variation in precipitation during 2006-2008 for the Drobeta Turnu-Severin location

was the Ieselnita location. The mean tritium concentration of $11.9 \pm 2.2 \mathrm{TU}$ for this location is close to the mean value measured for precipitation samples. The Sava River that flows into the Danube at Belgrade, with its discharge of $1564 \mathrm{~m}^{3} / \mathrm{s}$ (around 30\% of flow rate at the beginning of Lower Danube River), dilutes any influence from nuclear power plants situated near the Danube or its tributaries (Paks NPP in Hungary and Krcko NPP on Sava tributary). Two higher values than the average tritium concentration were recorded for the Bechet and Seimeni locations: $27.1 \pm 2.3$ and $31.4 \pm$ $2.3 \mathrm{TU}$, respectively. The 2 locations have 2 different nuclear power plants nearby: Kozloduy and Cernavoda. Kozloduy NPP has 3 WWER reactors (pressurized water reactor developed by the former Soviet Union) in operation with a typical tritium discharge rate in liquid effluents of $2.59 \times$ $10^{4} \mathrm{GBq} / \mathrm{Gw}(\mathrm{e})$ per year for each unit (IAEA 2004), and it is situated upstream of Bechet. Cernavoda NPP has 2 CANDU reactors in operation with a typical tritium discharge rate in liquid effluents of $1.85 \times 10^{5} \mathrm{GBq} / \mathrm{Gw}(\mathrm{e})$ per year for each unit (IAEA 2004), and is situated upstream of Seimeni. These higher values were recorded only in these locations, with downstream recorded values of $10.7 \pm 2.2 \mathrm{TU}$ (Tr.-Magurele location) and 11.6 $\pm 2.2 \mathrm{TU}$ (Giurgeni location).

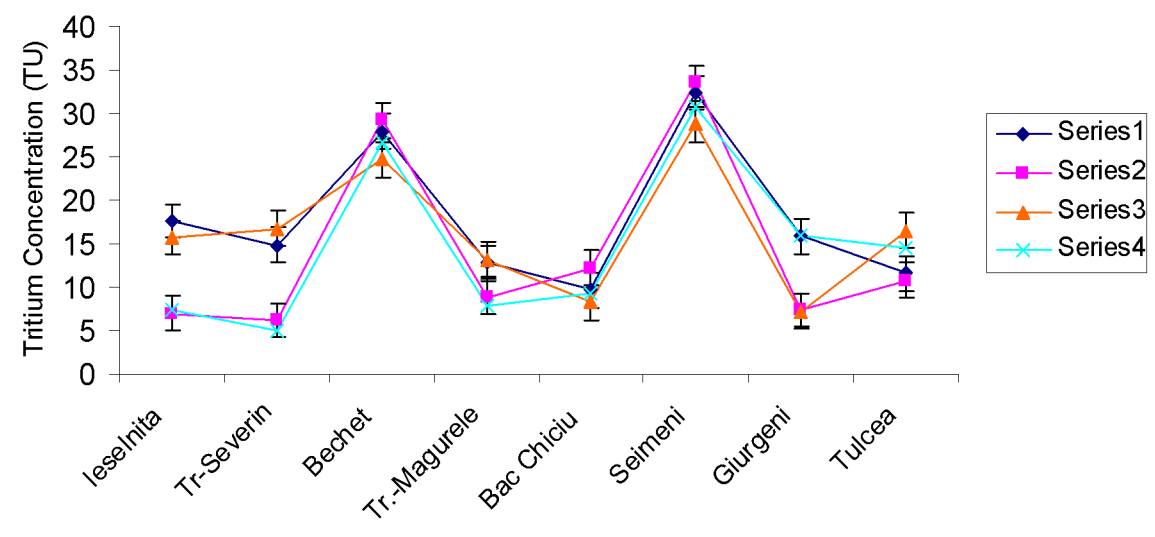

Sampling Locations

Figure 4 Tritium concentration in the Lower Danube Basin for the 4 sampling campaigns: August 2006 (series 1), March 2007 (series 2), October 2007 (series 3), and April 2008 (series 4). 
Tributaries had lower values than the tritium concentration average due to their different basins with strong groundwater components (Figure 5). The corresponding values ranged from $4.1 \pm 2.1 \mathrm{TU}$ (Cerna River, March 2007) to $12.7 \pm 2.2$ TU (Jiu River, August 2006). Higher tritium concentrations were recorded during the summer campaign of 2006 in almost all tributaries, the exception being the Olt River with important chemical industrial activities developed along its watercourse.

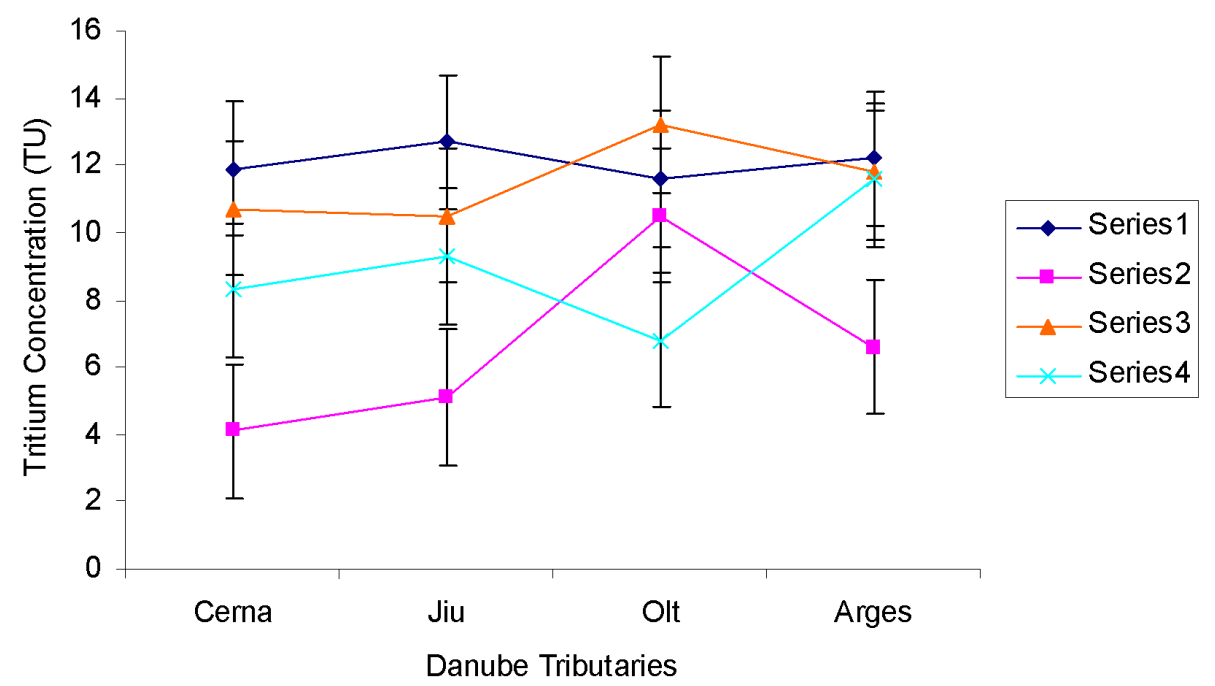

Figure 5 Tritium concentration in Danube tributaries for the 4 sampling campaigns: August 2006 (series 1), March 2007 (series 2), October 2007 (series 3), and April 2008 (series 4).

The highest mean tritium concentration measured during the 4 sampling campaigns for the Danube water was recorded in August 2006 (16.6 \pm 2.2 TU). The lowest mean tritium concentration measured during the 4 sampling campaigns for the Danube water was recorded in March 2007 (13.8 \pm 2.2 TU). This behavior, with higher tritium concentration in the warm months and lower tritium concentration in the cold months, suggests the annual fluctuation of precipitation. Environmental values recorded confirmed that precipitation is the primary source of tritium in the Danube water, in spite of the existence of the 2 important nuclear power plants in the monitored area, as previously mentioned. It must be noted that the tritium level in the Danube water is continuously decreasing from 20-25 TU in 1995 (Rank et al. 1999) to a precipitation level in the last few years.

To establish the necessary amount of water for ${ }^{14} \mathrm{C}$ measurements, several measurements have been carried out. The average values of the sampling campaigns are presented in Table 2. The $\mathrm{pH}$, conductivity, and temperature were measured on site at the sampling location. The measured $\mathrm{pH}$ in the field was in the range of 7.53 (for Arges tributary) and 8.62 (for Olt tributary).

The lowest recorded temperature was for the Cerna tributary (a mountain river). Conductivity along the Danube was $\sim 400 \mu \mathrm{S} / \mathrm{cm}$, and extreme values were recorded for tributaries: the lowest values of $305 \mu \mathrm{S} / \mathrm{cm}$ for the Cerna River and the highest values of $529 \mu \mathrm{S} / \mathrm{cm}$ for the Olt River. The major component of inorganic carbon in water was $\mathrm{HCO}_{3}{ }^{-}$with values varying from $109.8 \mathrm{mg} / \mathrm{L}$ (Olt River) to $164.7 \mathrm{mg} / \mathrm{L}$ (Arges River). In order to obtain the necessary quantity of $\mathrm{BaCO}_{3}, \sim 80 \mathrm{~L}$ of water had to be sampled and precipitated. The measured $\delta^{13} \mathrm{C}$ values varied along the Lower Danube Basin between $-7.8 \%$ at the beginning of this area and $-11.1 \%$ for Tulcea location 12 near the Danube Delta. Lower values were also recorded in the Danube Delta where $\mathrm{CO}_{2}$ derived from the oxidation of organic matter influenced the isotopic composition. 
Table 2 Physical-chemical characteristics and ${ }^{13} \mathrm{C}$ isotopic composition measured along the Romanian Lower Danube Basin.

\begin{tabular}{cllllllr}
\hline $\begin{array}{l}\text { Location } \\
\mathrm{nr}\end{array}$ & $\begin{array}{l}\text { Water } \\
\text { body }\end{array}$ & $\begin{array}{l}\mathrm{pH} \\
\text { in situ }\end{array}$ & $\begin{array}{l}\mathrm{T} \\
\left({ }^{\circ} \mathrm{C}\right)\end{array}$ & $\begin{array}{l}\mathrm{Cond} \\
(\mu \mathrm{S} / \mathrm{cm})\end{array}$ & $\begin{array}{l}\mathrm{HCO}_{3}{ }^{-} \\
(\mathrm{mg} / \mathrm{L})\end{array}$ & $\begin{array}{l}\mathrm{CO}_{3}{ }^{2-} \\
(\mathrm{mg} / \mathrm{L})\end{array}$ & $\begin{array}{l}\delta^{13} \mathrm{C} \\
(\%)\end{array}$ \\
\hline 1 & Danube & 7.59 & 16.0 & 404 & 152.5 & 6.0 & -7.8 \\
2 & Cerna & 7.94 & 14.7 & 305 & 125.0 & 3.0 & -9.3 \\
3 & Danube & 8.13 & 16.2 & 350 & 118.9 & 3.0 & -8.8 \\
4 & Jiu & 8.35 & 17.3 & 397 & 146.4 & 6.0 & -7.6 \\
5 & Danube & 8.62 & 16.8 & 529 & 109.8 & 6.0 & -8.2 \\
6 & Olt & 8.29 & 15.9 & 418 & 137.5 & 3.0 & -10.4 \\
7 & Danube & 7.53 & 16.1 & 483 & 164.7 & 6.0 & -8.4 \\
8 & Arges & 8.42 & 16.8 & 400 & 146.4 & 6.0 & -10.4 \\
9 & Danube & 8.17 & 15.7 & 437 & 152.4 & 6.0 & -9.6 \\
10 & Danube & 8.49 & 15.9 & 405 & 159.4 & 6.0 & -9.8 \\
11 & Danube & 8.19 & 16.4 & 416 & 125.0 & 3.0 & -8.7 \\
12 & Danube & 7.59 & 16.0 & 404 & 152.5 & 6.0 & -11.7 \\
\hline
\end{tabular}

${ }^{14} \mathrm{C}$ results from the Lower Danube River water are presented in Figure 6. Measured ${ }^{14} \mathrm{C}$ activity along the Danube had modern values. The average pMC for all sampling locations along the Romanian Lower Danube was $98.83 \pm 1.53$ pMC. This value has no practical meaning from an isotopic point of view, but it is a rough estimation of the ${ }^{14} \mathrm{C}$ content in the Danube for the $2 \mathrm{yr}$ of observation, from a radiological point of view.

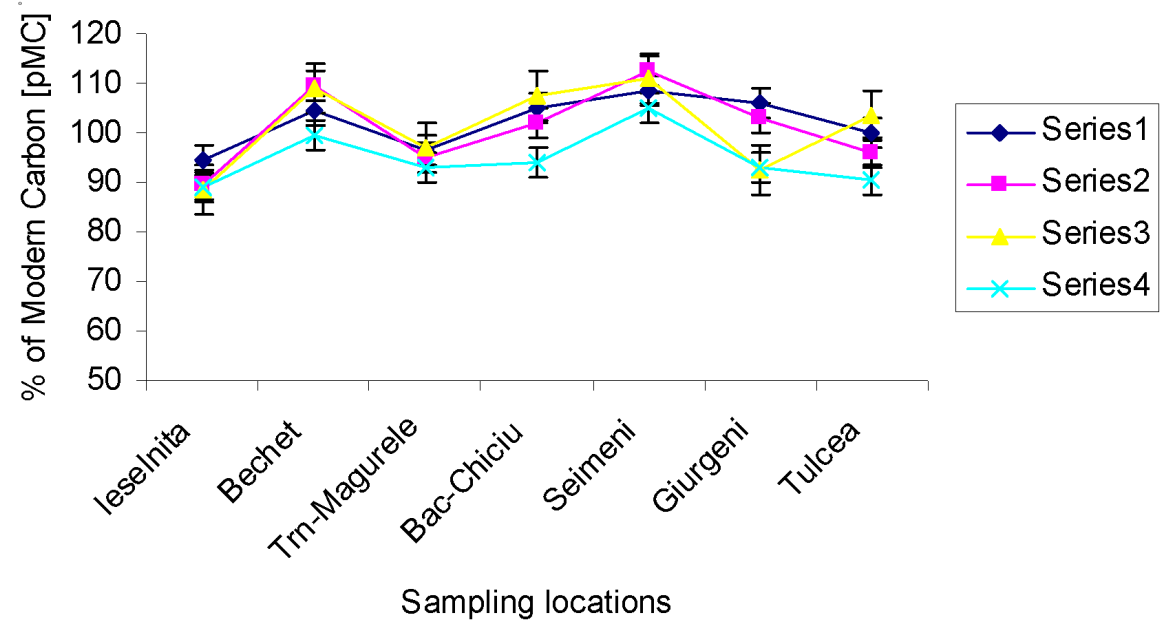

Figure 6 Percent of modern carbon in the Lower Danube River for the 4 sampling campaigns: August 2006 (series 1), March 2007 (series 2), October 2007 (series 3), and April 2008 (series 4).

Riverine processes affect the isotopic composition of the DIC content. These processes are more pronounced in stagnant surface waters. Exchange with atmosphere, direct oxidation of organic matter, and photosynthesis are only a few processes that are important for isotopic composition. These values can be biased by "old carbon" contributions, from various pre-age sources, or from the weathering of calcareous and/or siliceous rocks in the watershed (Rozanski et al. 2001). Unlike lakes, where the surface layer carbon is usually in equilibrium with the atmospheric carbon, and implicitly common values of 106-109 pMC could be encountered (Moreton et al. 2004), our sam- 
pling points values ranged from $88.45 \pm 1.46 \mathrm{pMC}$ at Ieselnita (March 2007) to $112.36 \pm 1.56 \mathrm{pMC}$ at Seimeni (March 2007). A mean value of ${ }^{14} \mathrm{C}$ content has been calculated for each sampling location for all 4 sampling campaigns. The lowest mean value was for the Ieselnita location (90.31 \pm $1.47 \mathrm{pMC}$ ). However, due to the particular conditions of each location, these mean values cannot be compared with each other. Another low mean of ${ }^{14} \mathrm{C}$ content was recorded in the Tr.-Magurele location (94.67 $\pm 1.51 \mathrm{pMC}$ ), downstream from the inflow of the Olt River. Other ${ }^{14} \mathrm{C}$ mean values varied between $97.6 \pm 1.52 \mathrm{pMC}$ (Tulcea location) to $102.01 \pm 1.53$ pMC (Bac Chiciu).

Higher values were constantly recorded for locations Bechet and Seimeni. The values ranged between $99.42 \pm 1.53$ (April 2008) and $109.48 \pm 1.55$ pMC (March 2007) for the Bechet location, downstream from the Kozloduy NPP, with a mean value of $105.5 \pm 1.54 \mathrm{pMC}$. The recorded values for the Seimeni location downstream from the Cernavoda NPP varied between $104.91 \pm 1.54$ (April 2008) and $112.36 \pm 1.56 \mathrm{pMC}$ (March 2007), with a mean of $109.2 \pm 1.55 \mathrm{pMC}$. This trend indicated nuclear activity for these locations. Downstream from these locations $(94.67 \pm 1.51 \mathrm{pMC}$ for the Turnu-Magurele location and $98.68 \pm 1.52 \mathrm{pMC}$ for Giurgeni), the registered mean values were lower than the calculated ${ }^{14} \mathrm{C}$ average content for the Danube, and so the impact of nuclear activities seems to be limited from a geographical point of view. Magnusson et al. (2004) reported excess levels of ${ }^{14} \mathrm{C}$ in grass within a distance of $\sim 1000 \mathrm{~m}$ of the Cernavoda NPP, the highest value being 311 $\mathrm{Bq} / \mathrm{kg}$ C. It was evaluated as an increase of $\sim 28 \%$ above the contemporary ${ }^{14} \mathrm{C}$ background. The background ${ }^{14} \mathrm{C}$ activity of $241 \pm 2 \mathrm{~Bq} / \mathrm{g}$ C measured in rush from Märyd, Sweden, was the mean value for 2002-2003 (Magnusson et al. 2004). To evaluate the impact of a nuclear power plant on Danube water, we consider it of great importance that the reference location for background ${ }^{14} \mathrm{C}$ activity be deep Danube water from nearby Cernavoda NPP.

Each tributary presented lower values than the established average for Danube ${ }^{14} \mathrm{C}$ content, thus indicating contributions from different groundwater reservoirs (Figure 7). These contributions were confirmed by lower tritium concentration measured in these tributaries. The tributaries mean ${ }^{14} \mathrm{C}$ content values varied between $71.20 \pm 1.33 \mathrm{pMC}$ for the Cerna River and $82.69 \pm 1.41 \mathrm{pMC}$ for the Arges River. The average ${ }^{14} \mathrm{C}$ content of downstream tributary inflows was also lower, e.g. location Turnu-Magurele downstream from the Olt River with an average ${ }^{14} \mathrm{C}$ content of $94.67 \pm 1.51 \mathrm{pMC}$.

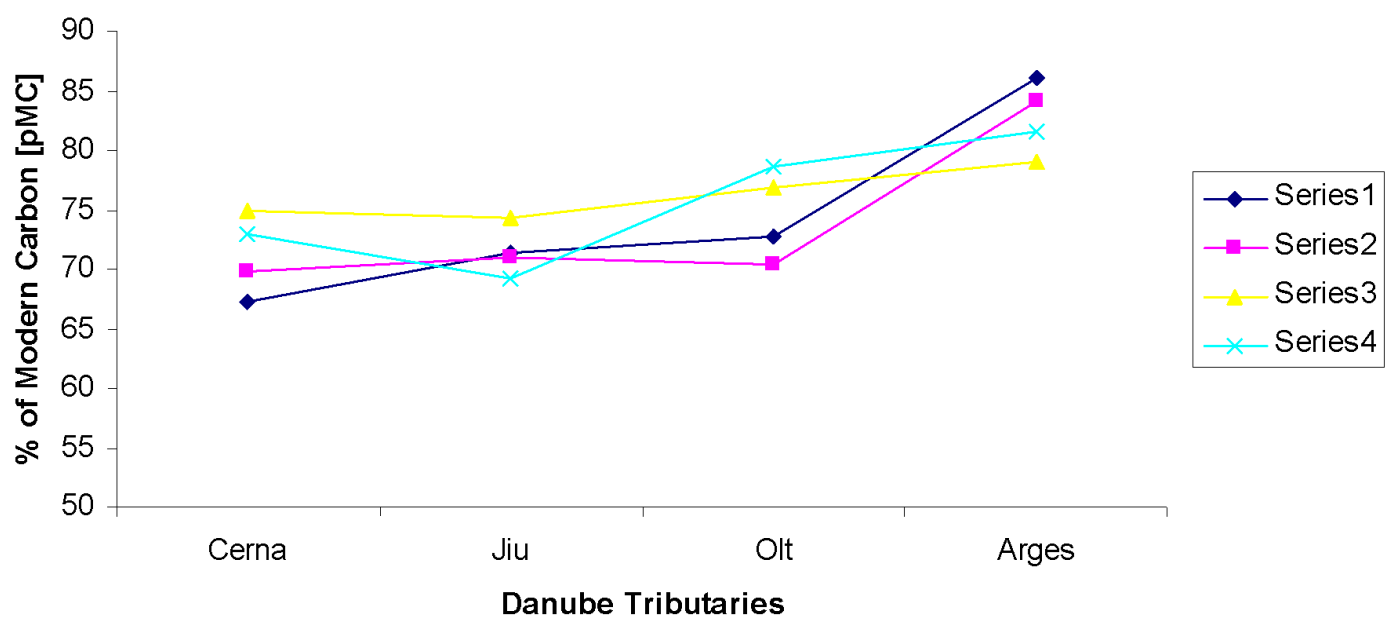

Figure 7 Percent of modern carbon in Danube tributaries for the 4 sampling campaigns: August 2006 (series 1), March 2007 (series 2), October 2007 (series 3), and April 2008 (series 4). 


\section{CONCLUSIONS}

Among the carbon isotopes, ${ }^{13} \mathrm{C}$ is the most used in environmental studies and has been widely applied in river studies. ${ }^{14} \mathrm{C}$ is especially suitable as a dating tool, but in our case it was needed for monitoring purposes. The averages of $105.5 \pm 1.54 \mathrm{pMC}$ for the Bechet location (downstream from the Kozloduy NPP) and 109.2 \pm 1.55 pMC for the Seimeni location (downstream from the Cernavoda NPP) are higher than the average ${ }^{14} \mathrm{C}$ content in the Danube water (98.83 $\left.\pm 1.53 \mathrm{pMC}\right)$, but are not of any radiological concern, as that kind of value can be found in ocean water (Druffel et al. 1992). In fact, there are some published studies (Davidescu 2002; Tenu et al. 2002) that indicate an increasing trend for ${ }^{14} \mathrm{C}$ atmospheric concentration in Cernavoda, ranging from 105 to 123 pMC.

Higher values for the same locations were recorded for tritium concentration also ( $27.1 \pm 2.3 \mathrm{TU}$ for Bechet, and $31.4 \pm 2.3 \mathrm{TU}$ for Seimeni). Despite the nuclear activity taking place in the monitored area, tritium behavior in the Danube water is similar to precipitation, with higher values in the warm months and lower values in the cold months. The highest mean tritium concentration of $16.6 \pm 2.2$ TU for the Danube water was recorded in August 2006. The lowest mean tritium concentration of $13.8 \pm 2.2 \mathrm{TU}$ for the Danube water was recorded in March 2007.

In most cases, surface water systems are an intermediate step between precipitation and a given archive, such as lacustrine sediments, groundwater, or organic matter. Despite the nuclear activity in the observed areas, tritium and ${ }^{14} \mathrm{C}$ activities present slightly higher values for specific locations without any influence on the receiving river. The reference locations for ${ }^{14} \mathrm{C}$ content in the Danube water will be settled near the alimentation basin for nuclear power plants and will include screening isotopic identification of suspended sediments in order to distinguish between carbonate precipitated in the river versus detrital carbonate originating caused by weathering and erosion of the watershed. The recorded values were a screening test for complex areas in a widespread area of 975 $\mathrm{km}$. Long-term tritium and ${ }^{14} \mathrm{C}$ monitoring activity has begun. The entire sampling strategy has been defined in order to provide the required data package for analyzing in a quantitative manner the influence of the nuclear activities along the Danube, and especially the environmental impact of the Cernavoda NPP.

\section{ACKNOWLEDGMENTS}

The authors wish to thank to all the colleagues from RAAN Drobeta Turnu-Severin, especially Mr Octavian Contes for his support in sampling activities.

\section{REFERENCES}

APHA-AWWA-WEF [American Public Health Association (APHA); American Water Works Association (AWWA); Water Environment Federation (WEF)]. 1995. Standard Methods for the Examination of Water and Wastewater. 19th edition. Washington: APHAAWWA-WEF.

Clark ID, Fritz P. 1997. Environmental Isotopes in Hydrogeology. Boca Raton: CRC Press. p 37-42.

Davidescu F, Petres R, Tenu A. 2002. Tritium and C-14 trends in the environment for Cernavoda Power Plant. Mediul Inconjurator 2(1):28-34. In Romanian.

Druffel ERM, Williams PM, Bauer JE, Ertel JR. 1992. Cycling of dissolved and particulate organic matter in the open ocean. Journal of Geophysical Research 97(C10):15,639-59.
IAEA (International Atomic Energy Agency). 1989. Measurement of Radionuclides in Food and the Environment. Technical Reports Series nr 295. Vienna: IAEA. p 30-1.

IAEA (International Atomic Energy Agency). 2004. Management of Waste Containing Tritium and Carbon-14. Technical Reports Series nr 421. Vienna: IAEA. 18 p.

ICPDR (International Commission for the Protection of Danube River). 2005. The Danube River Basin District Part A-Basin-wide Overview.

ISO (International Organization for Standards). 1989. Water quality. Determination of tritium activity concentration in water sample. Liquid Scintillation Method. ISO/DIS 9698. Geneva: ISO. 24 p. 
Kralik M, Hummer F, Stadler E, Scheidleder A, Tesch R, Papesch W. 2005. Tritium Osterreich Jahresbericht 1997 bis 2002. Available online at http://www.umweltbundesamt.at.

Leaney F, Herczeg A, Dighton J. 1994. New developments for the direct $\mathrm{CO}_{2}$ absorption method for radiocarbon analysis. Quaternary Science Reviews 13(2): 171-8.

Magnusson Ȧ, Stenström K, Skog G, Adliene D, Adlys G, Hellborg R, Olariu A, Zakaria M, Rääf C, Mattsson S. 2004. Levels of ${ }^{14} \mathrm{C}$ in the terrestrial environment in the vicinity of two European nuclear power plants. $R a-$ diocarbon 46(2):863-8.

Moreton SG, Rosqvist GC, Davies SJ, Bentley MJ. 2004. Radiocarbon reservoirs ages from freshwater lakes, south Georgia, sub-Antarctic: modern analogues from particulate organic matter and surface sediments. $\mathrm{Ra}$ diocarbon 46(2):621-7.

Rank D, Adler A, Araguás-Araguás L, Froehlich K, Rozanski K, Stichler W. 1998. Hydrological parameters and climatic signals derived from long term tritium and stable isotope time series of the River Danube. In: Proceedings, Isotope Techniques in the Study of Environmental Change. IAEA-SM-349/16. Vienna: IAEA. p 191-205.

Rank D, Özsoy E, Salihoğlu İ. 1999. Oxygen-18, deute- rium and tritium in the Black Sea and the Sea of Marmara. Journal of Environmental Radioactivity 43(2): 231-45.

Rank D, Papesch W, Tesch R. 2005. Runoff characteristics of the upper Danube basin: conclusions from long-term environmental isotope records. Geophysical Research Abstracts 7:03315.

Tenu A, Davidescu F, Cuculeanu V. 2002. Tropospheric $\mathrm{CO}_{2}$ in Romania: concentration and isotopic composition measurements. IAEA-TECDOC-1269. Vienna: IAEA. p 41-59.

Rozanski K, Froehlich K, Mook WG. 2001. Environmental isotopes in the hydrological cycles. In: Mook WG, editor. IHP-V, Technical Documents in Hydrology. Number 39. Volume 3. Paris: UNESCO. p 39-45.

Varlam C, Stefanescu I, Varlam M, Faurescu I, Popescu I. 2005. Optimization of ${ }^{14} \mathrm{C}$ concentration measurement in aqueous samples using direct absorption method and liquid scintillation counting. In: Chałupnik S, Schönhofer F, Noakes F, editors. LSC 2005, Advances in Liquid Scintillation Spectrometry. Tucson: Radiocarbon. p 423-8.

Varlam C, Stefanescu I, Duliu OG, Faurescu I, Popescu I, Dobrinescu D. 2009. Applying direct liquid scintillation counting to low level tritium measurement. Journal of Applied Radiation and Isotopes 67(5):812-6. 